\title{
Effect of Stabilization on Failure Susceptibility of Oshogbo-Iwo Road in South-Western Nigeria
}

\author{
Oluyemi-Ayibiowu Bamitale Dorcas ${ }^{1}$, Omomomi Oladapo Jayejeje and Fadugba Olaolu George ${ }^{\star 凶}$ \\ Civil Engineering Department, Federal University of Technology, Akure, Nigeria. \\ ${ }^{\star}$ Corresponding author's Email: ogfadugba@futa.edu.ng;: (D) ORCiD: 0000-0003-4065-8598
}

\begin{abstract}
The research evaluated the failure susceptibility of biopolymers (Guar Gum, Xanthan Gum, Bentonite) and polyvinyl acetate (PVAc) stabilized soil samples from three failed locations along Oshogbo - Iwo Road's using the TDRAMS mathematical model formulated by Aderinola et al., (2015). The stabilizers were added to the soils in concentrations of (0.25-2) \% Biopolymers, (1-3) \% Bentonite and 2\% PVA $_{c}$. The samples were classified according to AASHTO as A-5 (slty-sand) and ML group (inorganic silts, sfine sands with low plasticity) based on USCS classification system. Geotechnical tests carried out on both natural untreated and treated samples showed that the natural soil samples gave OMC values of between (11.7-14.97) \%, MDD (1644-1453.6) Kg/m $\mathrm{m}^{3}$, and soaked CBR (2-6) \%. 1\% Guar gum, $1 \%$ Xanthan gum, 3\% Bentonite and 2\% Poly vinyl Acetate were deduced to be optimal mixes for improved strength. However, Guar gum was observed to be the best stabilizer. With the TDRAMS model, $1 \%$ Guar gum reduced the failure susceptibility indices of the road by $11.02 \%$ (i.e. from 127 to 113). However, for maximum benefits to be achieved from the stabilization, other factors like provision of good drainage facilities, adequate road sections etc. must be provided. This will help in improving the strength of the subgrade soils and overall durability of the road.
\end{abstract}

Keywords: Stabilization, Guar Gum, Xanthan Gum, Polyvinyl acetate, Failure Susceptibility

\section{INTRODUCTION}

In Nigeria today, it's no surprise to drive along dilapidated road pavements. Many roads instead of providing safe passage to destinations, have long become death traps (Una, 2011). One of such roads is the Oshogbo-Iwo road located in Osun state, Southwestern Nigeria. It lies within latitudes $7^{\circ} 37^{\prime} 36.24 " \mathrm{~N}$ and $7^{\circ} 47^{\prime} 22.08^{\prime \prime} \mathrm{N}$ and longitudes $4^{\circ} 09^{\prime} 22.20^{\prime \prime} \mathrm{E}$ and $4^{\circ} 30^{\prime} 23.58^{\prime \prime}$ E. The road connects Oshogbo to many other cities in Osun state like Ede, Ejigbo, Iwo, Ikire, Ogbagbaa etc. and links the state to Ibadan and many other parts of Oyo state. However, the incessant failure of the road pavement has negatively affected the socio-economic activities within the area and this needs urgent solution (Figure 1).

A number of researchers (Ola et al., 2009; Oluyemiayibiowu et al., 2016; Owolabi and Ola, 2014; Quadri et al., 2018, Ola et al., 2019; Oluyemi-ayibiowu et al., 2020; Ola et al., 2020) have investigated the road in order to investigate the cause but also provide a solution to the road's incessant failure. Oyelami and Alimi (2015) also investigated the possible causes of the persistent failure along the road samples were taken along different failed sections of the road following a geological mapping of the area. The results of the geological mapping revealed that the road pavement is underlain by schist with pegmatite intrusion, whose minerals have weathered into expansive clay.

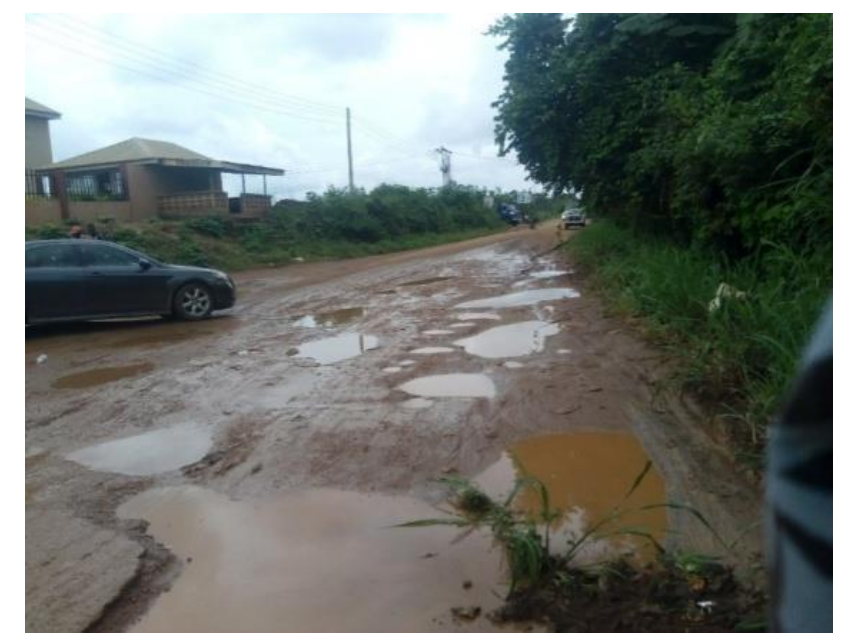

Figure 1. Typical Failed Sections of Oshogbo Iwo Road.

Soil stabilization technique had been employed to improve the soil materials along the road. Alteration of the soil's engineering properties through mechanical or chemical means is employed especially when it is more economical to overcome a deficiency in areadily available material than to bring in one that fully complies with the 
requirements of specification for the soil (Ola, 1975). Quadri et al. (2018) improved the quality of the subgrade material with the use of portland cement and Renolith (a synthetic polymer) to stabilize the soil samples collected from four different locations along the road. Based on this work, the use of $5 \%$ cement and $4 \%$ Renolith by weight of soil sample was recommended to improve the subgrade soil to a sub-base material.

In recent times, the use of environmentally friendly additives like Biopolymers, Polyvinyl Acetate Bentonite and are currently being investigated as replacements for conventional stabilizers like lime and cement (Ayeldeen et al., 2017; Guo, 2014; Jang, 2020; Khattab et al., 2007; Latifi et al., 2017; Muguda et al., 2017; Oluyemiayibiowu, 2015; Oluyemi-Ayibiowu and Fadugba, 2019; Soldo and Mileti, 2019; Rendón-Villalobos et al., 2016). Biopolymers are polymers that are produced by living organisms. The most commonly used biopolymer in recent times includes polysaccharides, which are polymeric carbohydrate chains composed of monosaccharide units (Lorenzo et al., 2012). Polyvinyl Acetate (PVAc), on the other hand is a synthetic polymer. PVAc is a type of organic aqueous polymer soil stabilizer. Its main component is acetic-ethylene-ester. It comprises of many long-chain macromolecules and polarity carboxyl groups (-OOCCH3). Bentonite, which comprises mainly of montmorillonite is often used as drilling mud for oil and gas wells and boreholes. It has the potential to adjust soil gradation and improve its geotechnical characteristics.

Aderinola et al. (2015) considered the contribution of traffic[T], water-table[D], geotechnical indices such as Maximum Dry Density and California Bearing Ratio[M] and $[R]$, road cross-section elements such as cambering[A] and asphalt thickness[S] to determine the road's pavement failure indices. The research came up with a mathematical model called TDRAMS, which was used to determine the failure susceptibility of some soil samples from Oshogbo Iwo road.

This is a potent tool in assessing road pavement failure susceptibility at failed segments of any road. From the work, the soil samples were of high failure indices, and non-conformity in the construction of Oshogbo-Iwo road from the engineering specifications, both in material and in workmanship were deemed to be responsible for the road's incessant failure. This work therefore further investigated the use of Biopolymers (Guar gum and Xanthan gum), Polyvinyl Acetate and bentonite to improve the engineering properties of the Osogbo-Iwo Road soil and assess the stabilized failure susceptibility indices using the TDRAMS model.

\section{MATERIALS AND METHODS}

The soil investigation was carried out under standard laboratory conditions on soil samples which were obtained along 3 different sections of Oshogbo -Iwo road, Osun state. Sample A was collected at a location with coordinates, longitude $77936711 \mathrm{~N}$ and latitude 4.4909929E; sample B from Longitude 7.794651N and Latitude 4.4877133E; and sample c from Longitude 7.794651N and Latitude 4.48779677E (Figures 2 and 3). The soil samples were taken at a depth of $1.1 \mathrm{~m}$ below the ground level using undisturbed and disturbed sampling kept in black sacks to prevent moisture loss. Testing was performed at the Geotechnical Laboratory, Civil Engineering Department of the Federal University of Technology, Akure, Ondo State, Nigeria.
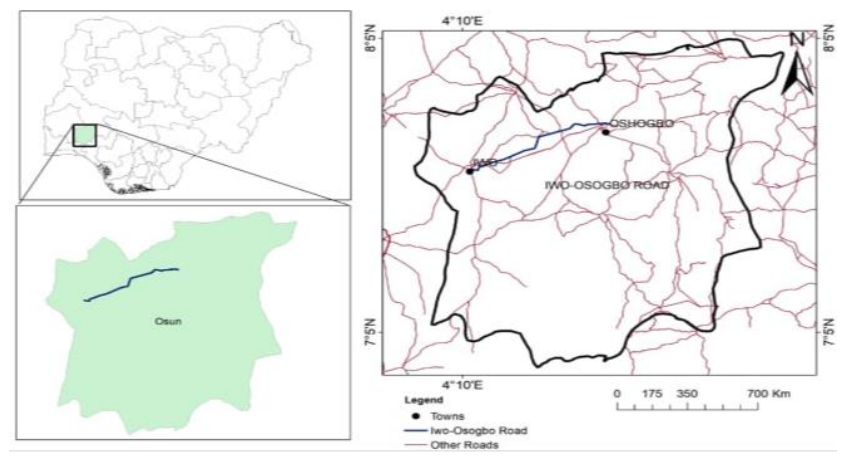

Figure 2. Map of Osun State, Nigeria

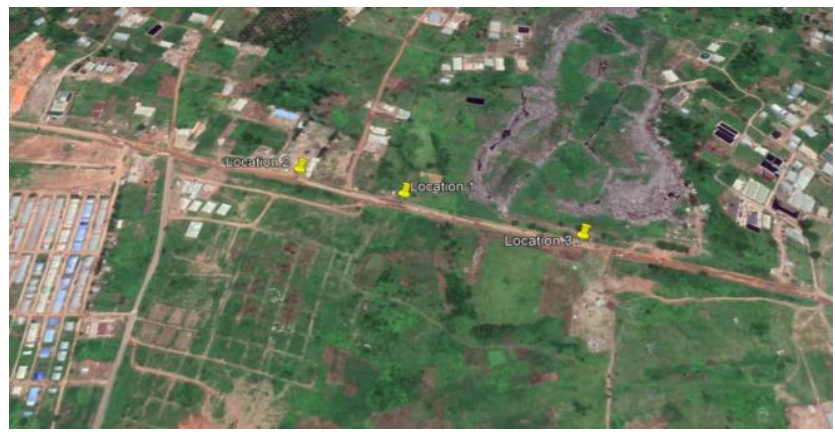

Figure 3. Sample locations (1-3).

Two commercially available biopolymers were used in this study (i.e. Xanthan gum and Guar gum) due to their availability and reasonable prices compared to other biopolymers. Also Polyvinyl Acetate (PVAc) was also applied as another stabilizer in the study. Polyvinyl acetate is synthesized by the polymerization reaction of polyvinyl alcohol and vinyl acetate in the presence of per sulfate as a free radical initiator in the reaction kettle commonly used for polymerization (Bu et al., 2019). Commercially available PVAc was used in this study. Bentonite is a clay formed as a result of chemical weathering of volcanic ash. It consists predominantly of smectite minerals, usually montmorillonite $\left[\mathrm{Si}_{8} \mathrm{Al}_{4} \mathrm{O}_{20}(\mathrm{OH})_{4} \cdot \mathrm{nH}_{2} \mathrm{O}\right]$. 
Commercially available bentonite was used for the research.

\section{Sample preparation}

To prepare treated soil specimens, the natural collapsible soil was disturbed by hand and air dried for one week. Wet mixing approach was employed in preparing stabilized samples, the stabilizers were first prepared with specific concentrations and then mixed with the air-dried soil. The percentage concentrations of Bentonite, Biopolymers and Polyvinyl Acetate (PVAc) used are $(1-3) \%,(0.25-2) \%$ and $2 \%$ respectively. The solution concentration in each case was calculated as a ratio between the weight of the used additive and the overall percentage by weight of the solution. The powdered additives (Guar gum and Xanthan gum) were added to the water gently to avoid clumping and mixed until a homogeneous solution was obtained

\section{Experimental programme}

Preliminary tests which included moisture content, Atterberg limit, Particle size distribution and specific gravity were conducted to determine the natural soil's index properties according to the procedures in BS1377 (1990). The soils were classified using the American Association of State Highway and Transportation Officials (AASHTO, 1986) and Unified Soil Classification System (USCS) (ASTM, 1992). West African Standard (WAS) Compaction Tests were carried out on both the natural and stabilized samples in accordance with the Nigeria General Specifications (1997). Unconfined Compressive Strength (UCS) was used to test the ability of the soil samples to withstand failure by compression. The natural and stabilized specimens were subjected to testing by crushing and the load that caused the failure of the specimen was divided by the cross sectional area of the specimen and the strength of the soil was determined following the procedure in BS1377 (1990). The samples were cured for 7 days in order to see the effect of time on the strength of the treated materials. The California bearing ratio (CBR) test developed by the California State Highway Department was used for the evaluation of road sub grade strengths at the selected failed locations. The test was carried out on soaked and un-soaked samples according to the procedure in BS1377(1990).

\section{RESULTS AND DISCUSSIONS}

\section{Natural soil characteristics}

The grain size curves of the samples from the three sections of the Oshogbo-Iwo road are shown in Graph 1. The grain size distribution can be taken as classical particle distribution for unstable soils with a large component of the soil being silty-fine to medium-fine sand and the (1124.3) \% clay acting as binder to bind the particles together. It can be deduced that the silt controls the behavior of the soil. The typical range of specific gravity for silty sand is between 2.67 and 2.7 (Karkush, 2018). The sample was classified as ML group (inorganic silts, fine sands with low plasticity) according to the unified soil classification system (USCS) and as an A-5 material (silty sand) which is fair -poor in terms of general ratings as a subgrade material according to the AASHTO classification system. Table 1 shows the natural soil characteristics.

Table 1. Geotechnical properties of the untreated soil.

\begin{tabular}{|c|c|c|c|}
\hline Grain size distribution & $\begin{array}{c}\text { Location } \\
1\end{array}$ & $\begin{array}{c}\text { Location } \\
2\end{array}$ & $\begin{array}{c}\text { Location } \\
\mathbf{3}\end{array}$ \\
\hline Gravel (\%) (>4.75 mm) & 26.5 & 36 & 31.7 \\
\hline Sand $(\%)(4.75-0.075 \mathrm{~mm})$ & 29.8 & 26.3 & 30.5 \\
\hline Silt (\%) (0.075-0.002 mm) & 31.8 & 24.6 & 13.5 \\
\hline Clay $(\%)(<0.002 \mathrm{~mm})$ & 11.9 & 13.1 & 24.3 \\
\hline Natural moisture content (\%) & 5 & 7.5 & 5.6 \\
\hline Specific Gravity (Gs) & 2.68 & 2.7 & 2.65 \\
\hline \multicolumn{4}{|l|}{ Atterberg limits } \\
\hline Liquid limit (\%) & 26.1 & 26.3 & 34.1 \\
\hline Plastic limit (\%) & 16.0 & 16.5 & 20.3 \\
\hline Shrinkage limit (\%) & 11.0 & 11.5 & 13.0 \\
\hline Plasticity index (\%) & 10.1 & 9.8 & 13.8 \\
\hline $\mathrm{OMC}(\%)$ & 11.7 & 14.57 & 14.97 \\
\hline $\operatorname{MDD}\left(\mathrm{kN} / \mathrm{m}^{3}\right)$ & 1644 & 1489.61 & 1453.60 \\
\hline CBR Un-soaked (\%) & 10 & 17 & 10 \\
\hline CBR Soaked (\%) & 3 & 6 & 2 \\
\hline $\mathrm{UCS}\left(\mathrm{kN} / \mathrm{m}^{2}\right)$ & 75.92 & 63.61 & 71.82 \\
\hline ASSHTO classifcation & A-5 & A-5 & A-6 \\
\hline USCS Classification & ML & ML & $\mathrm{CL}$ \\
\hline
\end{tabular}

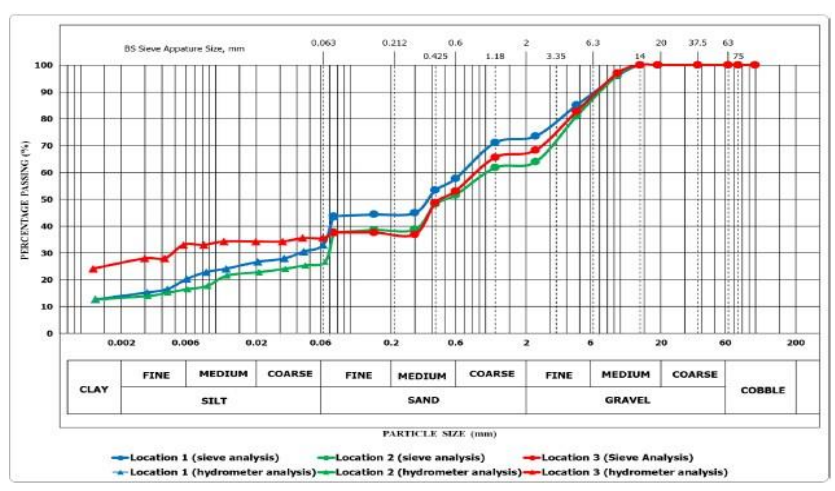

Graph 1. Grain size distribution for location (1-3). 


\section{Effect of additives on the soil's geotechnical characteristics}

The effects of the addiives on the compaction and strength properties of the soil are shown in tables 2 and 3.

\section{indices \\ Determination of stabilized failure susceptibility}

The Total TDRAMS Index (Aderinola et al., 2015) is mathematically expressed as:

T. TDRAMS.I $=b_{0}+b_{1} T+b_{2} D+b_{3} R+b_{4} A+b_{5} M+b_{6} S+e_{r}$.

Where: $b_{0}, b_{1}, b_{2}, b_{3}, b_{4}, b_{5}, b_{6}$ are the independent variables for the regression models and $e_{r}$ is the error coefficient.
This equation can also be written as:

T. TDRAMS.I $=6 \mathrm{~T}_{\mathrm{r}}+5 \mathrm{D}_{\mathrm{r}}+4 \mathrm{R}_{\mathrm{r}}+3 \mathrm{~A}_{\mathrm{r}}+2 \mathrm{M}_{\mathrm{r}}+\mathrm{S}_{\mathrm{r}}$

Where, 6, 5, 4, 3, 2 and 1 are the assigned weights of traffic load [T], depth to water-table [D], soaked CBR [R], cambering $[\mathrm{A}]$, maximum dry density $[\mathrm{M}]$, and asphalt thickness [S] respectively as shown in Table 4, TDRAMS Rating System and Weights (Ola et al., 2009). This was used to evaluate the failure indices in order to further ascertain the effectiveness of the stabilizers.

Table 2. Compaction characteristics of control and stabilized samples.

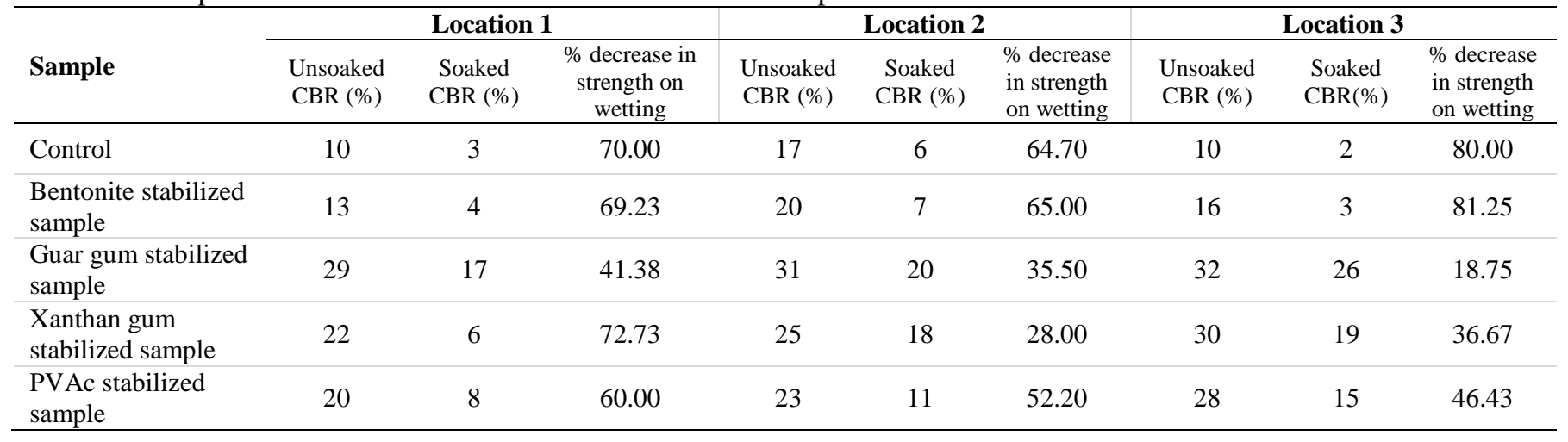

Table 3. California bearing values of stabilized samples.

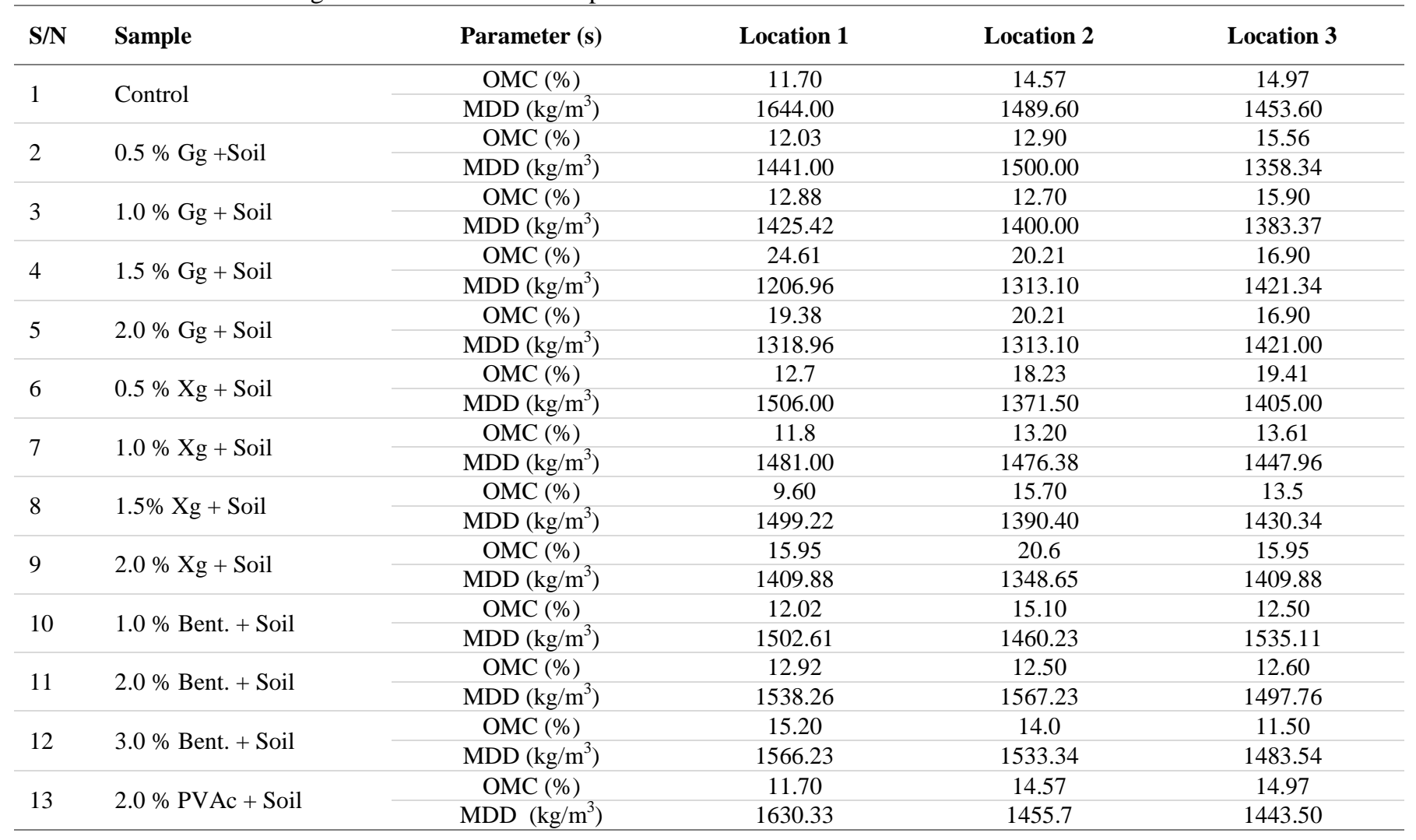




\section{Natural and stabilized soil failure indices}

According to Aderinola et al. (2015), Osogbo-Iwo road has 16 monitoring wells labeled MW1 through to MW16. From Tables 5-7, the CBR values are 20\%,19\%, $11 \%, 22 \%, 23 \%, 18 \%, 45 \%, 54 \%, 16 \%, 49 \%, 9 \%, 34 \%$, $69 \%, 39 \%, 14 \%$ and $50 \%$ for MW1 to MW16 respectively. The failure indices for the natural subgrade soils for MW1 to MW16 are 121, 127, 158, 150, 133, 141, $118,131,133,115,158,140,132,141,145,63$ respectively. According to Aderinola et al. (2015), the TDRAMS index for an ideal case scenario where the Depth to water table is farthest to the road pavement, soaked CBR is $50 \%$ and above, cambering is $3.75 \%$ on the average, Maximum dry density (MDD) is $2.1 \mathrm{KN} / \mathrm{m}^{3}$ and asphalt thickness computed under the control monitoring well is 63 . This is the numerical score that indicates the least failure susceptibility degree.

The TDRAMS Index values for the stabilized samples which were computed using equation (1) are shown in Table 4. The stabilizers had varying levels of improvement on the failure indices of the soil with the highest levels of improvements (11.02\%) decrease in the failure susceptibility indices) recorded by Guar gum at Location 2 MW2 and the least level of improvement (-7.59 \%) recorded at Location $3 \mathrm{MW} 3$ as shown in Table 8.

Table 4. TDRAMS Rating system and weights (Ola et al., 2009).

\begin{tabular}{|c|c|c|c|c|}
\hline Parameter & Range & Mean & Rating & Weight \\
\hline \multirow{8}{*}{$\begin{array}{l}{[\mathrm{T}]} \\
\text { Traffic Load }(\mathrm{KN})\end{array}$} & $0-25$ & 12.5 & 1 & \multirow{8}{*}{6} \\
\hline & $25-50$ & 37.5 & 2 & \\
\hline & $50-75$ & 62.5 & 5 & \\
\hline & $75-100$ & 87.5 & 8 & \\
\hline & $125-150$ & 112.5 & 10 & \\
\hline & $150-175$ & 137.5 & 12 & \\
\hline & $175-200$ & 165.5 & 14 & \\
\hline & $200+$ & 187.5 & 16 & \\
\hline \multirow{7}{*}{$\begin{array}{l}\text { [D] } \\
\text { Depth to water table (m) }\end{array}$} & $0-0.4$ & 0.2 & 10 & \multirow{7}{*}{5} \\
\hline & $0.4-0.8$ & 0.6 & 8 & \\
\hline & $0.8-1.2$ & 1.0 & 6 & \\
\hline & $1.2-1.8$ & 1.5 & 4 & \\
\hline & $1.8-2.2$ & 2.0 & 3 & \\
\hline & $2.2-2.6$ & 2.4 & 2 & \\
\hline & $2.6-3.00+$ & 2.8 & 1 & \\
\hline \multirow{6}{*}{$\begin{array}{l}{[R]} \\
\text { Sub-grade CBR Soaked (\%) }\end{array}$} & $0-10$ & 5 & 9 & \multirow{6}{*}{4} \\
\hline & $10-20$ & 15 & 7 & \\
\hline & $20-30$ & 25 & 5 & \\
\hline & $30-40$ & 35 & 4 & \\
\hline & $40-50$ & 45 & 2 & \\
\hline & $50+$ & & 1 & \\
\hline \multirow{5}{*}{$\begin{array}{l}{[\mathrm{A}]} \\
\text { Cambering }(\%)\end{array}$} & $0-0.75$ & 0.375 & 8 & \multirow{5}{*}{3} \\
\hline & $0.75-1.5$ & 1.125 & 7 & \\
\hline & $1.5-2.25$ & 1.875 & 5 & \\
\hline & $2.25-3.00$ & 2.625 & 3 & \\
\hline & $3.75+$ & & 1 & \\
\hline \multirow{6}{*}{$\begin{array}{l}{[\mathrm{M}]} \\
\operatorname{MDD}\left(\mathrm{Kg} / \mathbf{m}^{3}\right)\end{array}$} & $0-400$ & 200 & 10 & \multirow{6}{*}{2} \\
\hline & $400-800$ & 400 & 8 & \\
\hline & $800-1200$ & 600 & 5 & \\
\hline & $1200-1600$ & 1000 & 4 & \\
\hline & $1600-2100$ & 1400 & 2 & \\
\hline & $2100+$ & & 1 & \\
\hline \multirow{5}{*}{$\begin{array}{l}\text { [S] } \\
\text { Asphalt Thickness (m) }\end{array}$} & $0-0.01$ & 0.005 & 7 & \multirow{5}{*}{1} \\
\hline & $0.01-0.02$ & 0.015 & 6 & \\
\hline & $0.02-0.03$ & 0.025 & 5 & \\
\hline & $0.03-0.04$ & 0.035 & 4 & \\
\hline & $0.04-0.05$ & 0.045 & 2 & \\
\hline
\end{tabular}

*weights of traffic load [T], depth to water-table [D], soaked CBR [R], cambering [A], maximum dry density [M], and asphalt thickness [S] 
Table 5. Natural Soil Failure Indices (Aderinola et al., 2015).

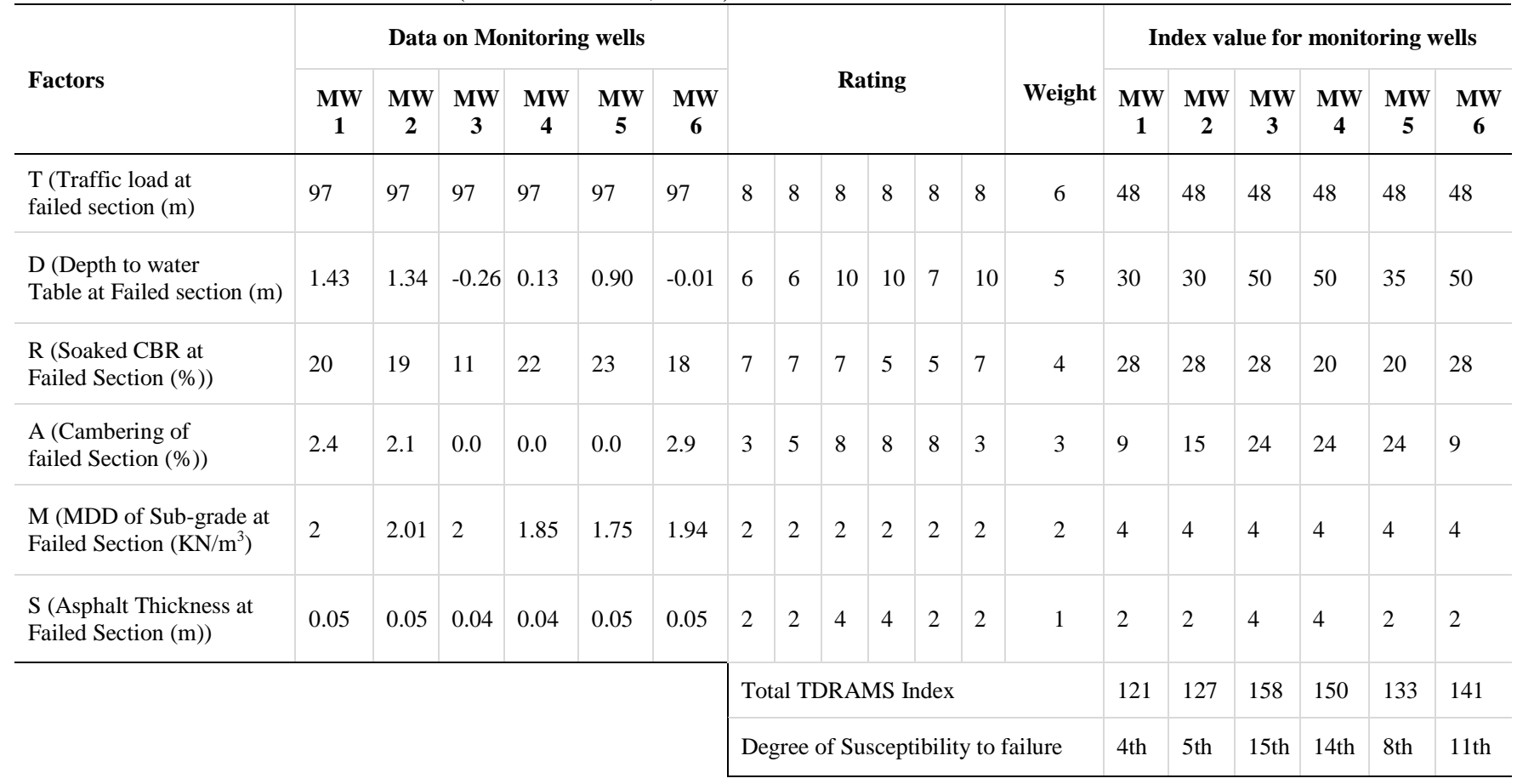

Table 6. Natural Soil Failure Indices (Aderinola et al., 2015).

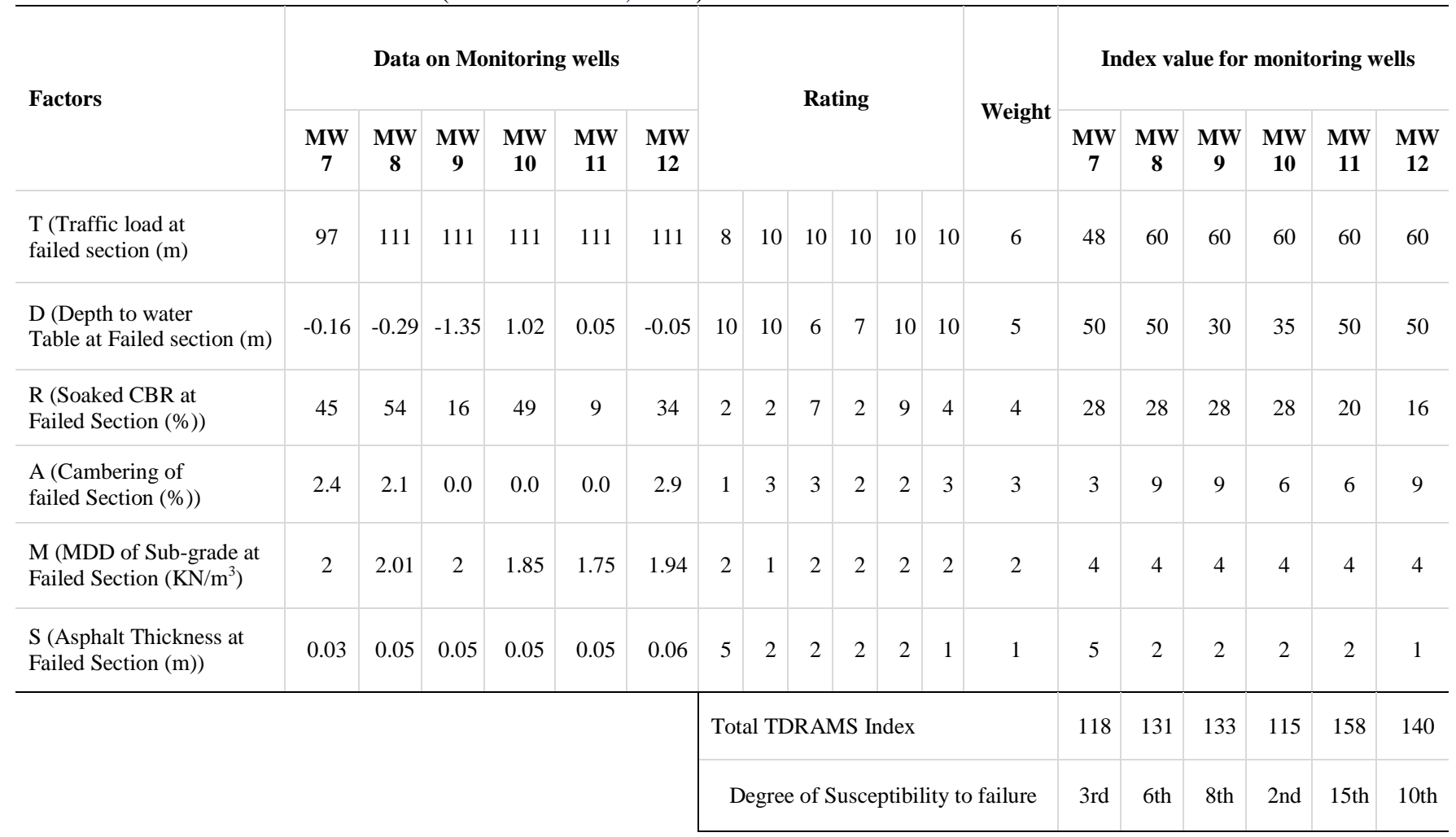


Table 7. Natural Soil Failure Indices (Aderinola et al., 2015).

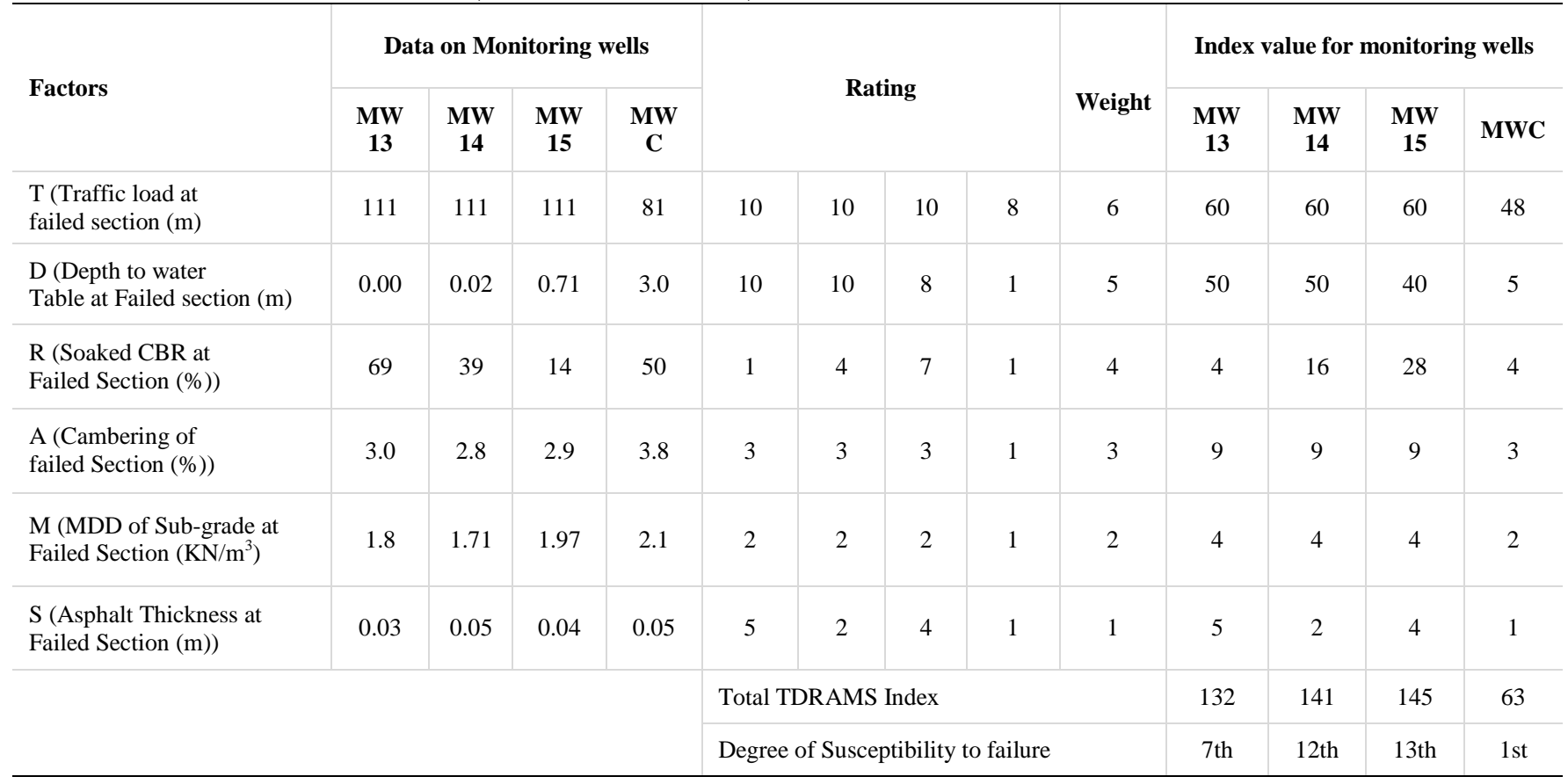

Table 8. Comparison between Natural and Stabilized failure susceptibility indices.

\begin{tabular}{llccc}
\hline Items & $\begin{array}{c}\text { Monitoring Well } \\
(\mathbf{M W})\end{array}$ & $\begin{array}{c}\text { Natural soil Index } \\
\text { (Control) }\end{array}$ & $\begin{array}{c}\text { Stabilized Index using } \\
\text { Rating and weight Model }\end{array}$ & $\begin{array}{c}\text { Percentage Decrease } \\
(\%)\end{array}$ \\
\hline \multirow{3}{*}{ Guar gum } & Location 1 MW1 & 121 & 115 & 113 \\
& Location 2 MW2 & 127 & 154 & 1.96 \\
& Location 3 MW3 & 158 & 123 & 2.53 \\
Xanthan gum & Location 1 MW1 & 121 & 121 & -1.65 \\
& Location 2 MW2 & 127 & 162 & 4.72 \\
Location 3 MW3 & 158 & 123 & -2.53 \\
Bentonite & Location 1 MW1 & 121 & 170 & -1.65 \\
& Location 2 MW1 & 127 & 115 & -1.57 \\
Polyvinyl Acetate & Location 3 MW3 & 158 & 121 & -7.59 \\
& Location 1 MW1 & 121 & 162 \\
\hline
\end{tabular}

\section{CONCLUSION}

From this research carried out on the Osogbo-Iwo road soil, the following conclusions were drawn:

A) $11 \%$ Guar gum, $1 \%$ Xanthan gum, $2 \%$ Bentonite and $2 \%$ Polyvinyl Acetate were deduced to be optimal mixes. However, Guar gum was observed to be the best stabilizer.

B) $11 \%$ Guar gum reduced the failure susceptibility indices of the road by $11.02 \%$ (i.e. from 127 to 113) but did not meet the standard set by Aderinola et al. (2015) of a standard road due to the absence of other factors like good drainage facilities, adequate road sections etc.

\section{Recommendations}

Based on the present study, the following recommendation are made:

- In order to achieve best stabilized results and for durability of the road in service, adequate road sections with proper drainage facilities should be provided.

- Regular maintenance of roads should be undertaken as and when due to prevent critical deterioration of roads.

- Proper awareness should be given to professionals on the availability and use of locally available environmentally friendly construction materials. 
Proper awareness should be given to professionals on the availability and use of locally available environmentally friendly construction materials.

\section{DECLARATIONS}

\section{Author's contribution}

All the authors contributed equally to this work.

\section{Competing interests}

The authors declare that they has no competing interests.

\section{REFERENCES}

AASHTO (1986). Standard specification for transportation. In Material and methods of sampling and testig (14th ed.). Amsterdam Association of State Highway and Transportation Officials.

ASTM. (1992). Annual Book of Standards. In Amercan Society For Testing and Materials (Vol. 4, Issue 8). Google Scholar

Ayeldeen M, Negm A, El-Sawwaf M \& Kitazume M (2017). Enhancing mechanical behaviors of collapsible soil using two biopolymers. Journal of Rock Mechanics and Geotechnical Engineering, 9(2): 329-339. https://doi.org/10.1016/j.jrmge.2016.11.007

BS1377 (1990). Standard B. BS 1377-7-1990-methods of test for Soils for civil engineering purposes-Part 7: Shear strength tests (total stress). London: UK: British Standard institute. 1990. Google Scholar

Bu F, Liu J, Bai Y, Prasanna Kanungo D, Song Z, Kong F, Pan C (2019). Effects of the preparation conditions and reinforcement mechanism of polyvinyl acetate soil stabilizer. $\quad$ Polymers. $11(3)$ : 506. https://doi.org/10.3390/polym11030506; Google Scholar

Guo L (2014). Investigation of soil stabilization using biopolymers. Google Scholar

Jang J (2020). A Review of the Application of Biopolymers on Geotechnical Engineering and the Strengthening Mechanisms between Typical Biopolymers and Soils. Advances in Materials Science and Engineering, 2020, 116. https://doi.org/10.1155/2020/1465709; Google Scholar

Karkush M. (2018). Lectures of Soil Mechanics. https://www.researchgate.net/publication/324162566_Lectu res_of_Soil_Mechanics

Khattab SA, Bahhe SW and Al-Juari KA (2007). Role Of Clays Addition On The Stability Of Collapsible Soil Selected From Mosul City. Al-Rafidain Engineering, 15(4), 12-30. Google Scholar

Latifi N, Horpibulsuk S, Meehan CL, Abd Majid MZ, Tahir MM and Mohamad ET (2017). Improvement of problematic soils with biopolymer-an environmentally friendly soil stabilizer. Journal of Materials in Civil Engineering, 29(2):04016204. Google Scholar; https://doi.org/10.1061/(ASCE)MT.19435533.0001706

Muguda S, Booth SJ, Hughes PN, Augarde CE, Perlot C, Bruno
AW, Gallipoli D. (2017). Mechanical properties of biopolymer-stabilised soil-based construction materials. Géotechnique letters. 7(4):309-14. Google Scholar; https://doi.org/10.1680/jgele.17.00081

Nigeria General Specifications. (1997). Federal Ministry of Works and Housing. Testing for the Selection of Soil for Roads and Bridges, Vol II. Google Scholar

Ola, S. A. (1975). Stabilisation of Nigerian Lateritic Soils with Cement. 6th Regional Conference For Africa on Soil Mechanics and Foundation Engineering, 145-152. Google $\underline{\text { Scholar }}$

Ola, S. A., Adekoya, J. A., \& Ojo, J. S. (2009). Report of the Geotechnical Investigative Studies of Osogbo-Iwo Road. Akure. In CERAD FUTA .

Ola SA, Braimoh AS, Fadugba OG. (2019). Measurement and Estimation of Soil Water Characteristic Curve for Four Unsaturated Tropical Soils, Annals of Faculty Engineering Huneduara-international Journal of Engineering, Tome XVII (2019). Google Scholar

Ola SA, Harris FI, Fadugba OG (2020). Verification of The Effect of Lateralite on Soil Stabilization for Highway Construction, Annals of Faculty Engineering Huneduarainternational Journal of Engineering, Tome XVIII (2020). Google Scholar

Oluyemi-Ayibiowu BD, Akinleye TO, Fadugba OG, Olowoselu AS. (2020). Soil-Water Characteristics of Tropical Clay Soil under High and Low Suction Conditions. Journal of Geoscience and Environment Protection 8(11): 162-175. https/doi.org/10.4236/gep.2020.811010 ; Google Scholar

Oluyemi-ayibiowu BD (2015). Performance Characteristics Of Some Nigerian Problem Soils Stabilized With Ionic Stabilizer. Academ Arena, 7(10): 16-28. http://www.sciencepub.net/academia

Oluyemi-Ayibiowu BD and Fadugba OG. (2019). The stabilization of Lateritic soil Using Coir Fiber as Natural Reinforcement. International Journal of Science and Engineerig Invention, 5(02), 56-60. https/doi.org/10.23958/ijsei/vol05-i02/140; Google Scholar

Oluyemi-Ayibiowu BD, SA O, Owolabi AO. (2016). Assessment of Polyvinyl Acetate as Stabilizing Agents for some Nigerian Problem Soils. European International Journal of Science and Technology, 5(3), 153-170. Google Scholar

Owolabi TA and Ola SA (2014). Geotechnical properties of a typical collapsible soil in South-Western Nigeria. Electronic Journal of Geotechnical Engineering, 19 H(April 2014), 1721-1738. Google Scholar

Oyelami AC, Alimi SA. (2015). Geotechnical investigation of some failed sections along Osogbo-awo road, Osun-State, Southwestern Nigeria. Ife Journal of Science. 17(1):87-95. https://www.ajol.info/index.php/ijs/article/view/131798; $\underline{\text { Google Scholar }}$

Quadri AI, Olagbaye AJ and Abdulhaneed MI (2018). Renolith Appraisal on Lateritic Soils Along Oshogbo-Iwo Road in Southwest Nigeria. International Journal of Science and Qualitative Analysis, 4(1): 1-6. https://doi.org/10.11648/j.ijsqa.20180401.11 ; Google $\underline{\text { Scholar }}$ 
Rendón-Villalobos R, Ortíz-Sánchez A, Tovar-Sánchez E, Flores-Huicochea E. (2016). The Role of Biopolymers in Obtaining Environmentally Friendly Materials. Composites from Renewable and Sustainable Materials, 1(1): 152-159. https://doi.org/http://dx.doi.org/10.5772/65265 ; $\underline{\text { Google }}$ $\underline{\text { Scholar }}$
Soldo A and Miletić M. (2019). Study on Shear Strength of Xanthan Gum-Amended Soil. Sustainability. 11(21):6142. https://doi.org/10.3390/su11216142; Google Scholar

Una, O. V. (2011). Pavement design in Nigeria: A Case Study of Lagos-Ibadan Expressway. Covenant University, Ota,Ogun State, Nigeria. 